\title{
F.A. Hayek and Ordoliberalism: A Comparative Study
}

\author{
Nazmi Tolga TUNCER \\ tuncert@ekonomi.gov.tr
}

\section{F.A. Hayek ve Ordoliberalizm: Karşılaştırmalı Bir Çalışma}

\begin{abstract}
This paper is a comparative study of two lines of thought in political economy which can be related to the German city of Freiburg. The Freiburg School which is also known as Ordoliberalism, constituted one of the foundations of the economic order in postwar West Germany. On the other hand, Nobel Prize holder Austrian economist Friedrich August von Hayek, who spent a considerable part of his life in Freiburg, in University of Freiburg, strongly inspired the neo-liberal policies in the western world in the 80's. In this work, we analyse the main differences and similarities of these two liberal lines of economic thought.
\end{abstract}

Keywords

: Freiburg School, Hayek, Ordoliberalism, Constitutional Economics, Walter Eucken.

JEL Classification Codes : $\quad$ B15, F55, F59, 01, 019, N93.

\section{Özet}

$\mathrm{Bu}$ çalışma, Almanya'nın Freiburg kenti ile ilişkilendirilebilecek iki iktisadi düşünce akımını karşılaştırmalı olarak ele almayı amaçlamaktadır. Ordoliberalizm olarak da bilinen Freiburg Okulu, Almanya'da Nazi döneminde Freiburg Üniversitesi çevrelerinde doğmuş ve savaş sonrasında Batı Almanya'nın iktisadi felsefesinin temellerinden birini oluşturmuştur. Nobel Ekonomi Ödüllü Avusturyalı iktisatçı Friedrich August von Hayek ise yaşamının önemli bir bölümünü Freiburg'da, Freiburg Üniversitesi'nde geçirmiş ve fikirleriyle 80'lerdeki neo-liberal politikalara esin kaynağ oluşturmuştur. Bu çalışmada, temelde liberal ekonomiyi savunan bu iki düşünce akımının benzerlik ve farklılıkları araştırılmaktadır. 
Nazmi Tolga TUNCER 


\section{Introduction}

The Freiburg School or as it is also called "Ordoliberalism" is the name given to the school of thought initiated by Walter Eucken, Franz Böhm and Hand Grossman-Doerth in the middle of $30 \mathrm{~s}$ at the University of Freiburg. It is generally agreed that Freiburg School constituted the basis of the economic order of West Germany -social market economy- in the post-war period which makes this school of thought a focus of academic interest. (Goldschmidt \& Hesse, 2012: 1) In this paper, our aim will be to investigate the possible connections and similarities between Freiburg School and another liberal line of thought which was one of the most influential ones in the last century, namely Hayekian line initiated by Friedrich August von Hayek. In this search for links, we will give a special weight to understanding the basic imperatives of Hayekian line which, I believe, forms a more general and comprehensive system of thought. Then, in a comparative way we will look at the views on state and market of the two lines of thought. In the last part, we will state the main differences as well as the common grounds of the two lines.

\section{The Freiburg School}

To better understand the Freiburg School, we have to take into account some historical facts. Starting with the end of $19^{\text {th }}$ century, we observe a regularly increasing degree of concentration in economy in Germany. Moreover, we also see that the tendency towards cartelization in this leading economy of the world was directly or indirectly encouraged by the state. This fact, coming together with the heavy economic conditions after First World War and the atmosphere of political instability ended up with disastrous results for Germany: The national socialist regime was supported by the national cartels that saw this regime in their interest. There is no need to mention the devastating results of this fascist regime for the German nation and economy.

The main theme of Freiburg School, which can be claimed to begin with the "Ordo Manifesto" of Eucken, Böhm and Grossman-Doerth in 1936, was the reasons and remedies of this degeneration of competitive order. Their observation was the increasing tendency of relativism and fatalism in social sciences -for which they mainly accuse the historicist school of Schmoller and Marx-, which diminished the leading effect of social science on politics. This vacuum of influence was filled by influence of the interest groups. The state was too weak to resist against the pressures from the interest groups. As a result, the leading role of the state to maintain the order was dominated by individual interests. (Eucken, Böhm, Grossman-Doerth, 1936: 17-21) This problem cannot be seen as a single economic problem. This domination, sooner or later, will be reflected in the political life which will be undermining the legal order and threatening the democratic foundations of open societies. (Eucken, 1948: 30-34) 
Faced with the described problems, particularly in Germany, ordoliberalism presents itself as a third way, neither laissez faire nor a centrally planned economy. The only way to protect the democratic open societies is to establish and maintain a competitive order by the leadership of the state. The role of the state is necessary because the competitive order cannot survive on itself since there is always the danger of cartelization and domination of the order by private interests. This is not to mean that state will take part actively or intervene in the economy. The basic principles are free enterprise and free market economy. Rather, the state should take the necessary measures to institutionalize the competitive order (legislation) and act as a neutral agent of the society to fight with cartels and private interests trying to dominate the society. To achieve this, state should not be big but strong and effective. In this leading role of the state the guide should be joint efforts of social sciences especially law and economics. (Goldschmidt \& Hesse, 2012: 6-7)

\section{F.A. Hayek's Political Economy}

After having a basic idea on the Freiburg School, now we can go on with an introduction to Hayek's political economy. Friedrich Hayek was a student of famous Austrian economist Von Mises and the inheritor of the tradition of "Austrian Economics" in the $20^{\text {th }}$ century, which always looked with suspicion at the mainstream general equilibrium economics tradition. Hayek is also seen as one of the most influential liberal thinkers of the previous century and his system can be claimed as a resurrection of the classical liberal tradition. The reason for that is clear: Hayek's system, unlike mainstream neo-classical line based on general equilibrium framework and technical approach, consisted of elements from a wide range of social sciences like political science, psychology, economics and philosophy. (Vanberg, 2001: 6482)

In analyzing Hayek's political economy we are going to use a simple categorization proposed by Fleetwood (1995). Fleetwood divides the history of Hayekian line into three based on the methodological roots. The early Hayek (prior to 1936) sticks to empiricist ontology and that is why he is still interested in equilibrium as an anchor to his system. (Fleetwood, 1995: 6) Between 1936 and 1960, which Fleetwood calls Hayek II, breaks from this mainstream line and adapts a synthesis of subjective idealist epistemology and empirical realist ontology. But in this period his system still included inconsistencies and was not complete. Only after 1960, Fleetwood argues, Hayek adapted a transcendental realist position that allowed him to betray a comprehensive and consistent system, what Fleetwood calls Hayek III (Fleetwood, 1995).

Hayek's main problem was explaining the order in the society. Here, without getting into detail, it is worth discussing some main components of his system. One can talk about two important events that have motivated Hayek's direction of research. The 
first is the socialist calculation debate where his colleague von Mises took part against Oscar Lange and Paretians, -which later made him the strongest and stubborn opponent of socialism- and the debates on business cycle theory against the Cambridge Keynesians, namely Keynes and Sraffa. In both debates Hayek hold a free market position but especially in the later debate he seemed to have lost as Keynesian interventionism became unquestionably dominant in the academic circles until late $60 \mathrm{~s}$. He then began to work for establishing philosophical roots for his position. (Fleetwood, 1995: 92)

The key element in Hayekian system is knowledge. Hayek pointed out that the problems with the allocation of knowledge were critical in defending the free market position. The earlier Hayek (Hayek II) underlined the importance of the price mechanism of the market as the communication mechanism of knowledge. Thousands of individual decision makers with different preferences and budgets were simultaneously taking decisions and they were unconsciously reaching the knowledge of the others through the price signals. (Hayek, 1952: 92) He saw price mechanism as the true means for the discovery, communication and storage of knowledge. On the other hand, as we have mentioned before, Hayek rejected the neo-classical idea of equilibrium. Market transactions implied a continuous dynamic process and predictability or societal equilibrium could be represented by the word "order" for Hayek. This inevitably brought an inconsistency: If the price mechanism is the only true means for the discovery, communication and storage of knowledge (as Hayek was using before 1960), then we have an implicit assumption that the market prices reflect the true costs and benefits to the decision makers. But this is only possible under some kind of general equilibrium (walrasian) assumptions. Hayek realized this fact that there should be some other means of knowledge communication, discovery and storage for him to be able to reject the general equilibrium framework. Fleetwood argues that this was the ground of what he calls Hayek III, the final stage in the development of Hayek's political economy. (Fleetwood, 1995: 75)

Ignorance is an important point in understanding this system. Hayek argues that the level of complexity of the modern society makes it impossible for a person to collect every piece of knowledge necessary for her to make her future plans in a classical rational way. Since such a case-by-case rational calculation and design of plans are unavailable, the individual inevitably ignores some of the knowledge that otherwise would be used in a rational calculation. Rather, individuals rely on rules in their daily actions. (Vanberg, 1994: 112) These rules of conduct, which are either learned by the personal experience of the individual or inherited from the earlier generations, are tested against specific situations. In this sense, individuals, systematically and rationally disregard certain facts and knowledge they know in order to make better decisions. This is so because the probability that the individual will be able to use and digest all these facts for a particular case is not very high. (Vanberg, 1994: 113) So, the rules of conduct fill the gap in Hayekian system that we have mentioned. The rules of conduct are the primary mechanism by which knowledge is stored and transmitted. The price mechanism can only perform its signaling function if it is embedded within a suitable network of rules. (Fleetwood, 1995: 127) 
Rules of conduct together with communication system (price mechanism) allow an order to be established in the society. But it is critical to underline that this is a spontaneous order. It is spontaneous in the sense that it is the result of human actions but it is not designed by anybody. (Hayek, 1973: 45) It is an orderly result of the numerous individual decisions thorough the communication mechanism thanks to the wellestablished network of rules of conduct known to everyone. Spontaneous order is not the only type of order observed in the society. The collective decision making units in the society -the organizations- have to establish an internal order in them. A firm, for instance, should plan its internal activity quite strictly to be successful. It has to define centrally in detail, which departments will be doing what in which way and who is responsible for what in each department. But this type of internal order of organizations is quite different than the order of the society for Hayek. (Hayek, 1964: 461) The rules that they are governed by are of a prescriptive type telling individuals what to do (what Hayek calls 'commands'). This will work and is necessary for the organization since the level of complexity of the functions of an organization is limited.

Organizations and individuals meet at the market as decision-making units to pursue their ends. To govern the whole society by commands (by a centrally planned economy for example) is hardly possible because of the complexity and the information problems we have mentioned. So, at this level there should be general rules of the proscriptive type, which will allow the spontaneous market forces work efficiently and create an order. This would be the most efficient way in terms of utilizing and activating the dispersed knowledge in the society. (Vanberg, 2001: 6484)

As it is seen, rules have a critical importance in Hayekian political economy. Rules provide the basis that the order is found on. What type of an order will come out is determined by the rules. Hayek explains this approach with an analogy to the ordinary games: A game is an orderly process which is a result of different and often conflicting interests of the participants who obey and follow common rules. (Hayek, 1988: 154)

Hayek's distrust on human reason's ability to understand its society comprehensively makes him quite suspicious of any constructivist attempt. He is opposed to the constructivist rational tradition starting with Descartes and going on with Rousseau, Comte, Hegel and Marx. (Liglio, 2000: 51) This applies to the issue how the rules should be created and takes Hayek to an evolutionary position. Hayek is in favour of the relying on the stable rules inherited from the past, from the tradition rather trying to rationally construct them since these rules are tested by the time and carry the knowledge of past experiences. However, this does not mean that Hayek proposes to take the rules inherited as given without any criticism. Rather, he states that the ground for such a criticism for an output of a tradition must all the time be other outputs of a tradition which is not questionable. (Vanberg, 1994: 21). 


\section{A Comparative Look at Freiburg School and Hayekian Line of Thought}

After having established some basics about both lines of thought now we can start our comparative discussion. In this search for links and common grounds it will be proper to give some historical background first. It is surprising to see that although these two lines have a common problem - maintaining individual liberty-, common subject matters -market and competitive order- and arrived at similar results there exist comparatively rare explicit references to each others works. Even after Hayek personally met Eucken around 1947 and introduced him as the "unforgettable Eucken" with whom he had closest agreement on scientific and political questions on ceremonial occasions, this attitude was hardly reflected in his major works. The same is also true for the Freiburg side. (Streit \& Wohlgemuth, 1997: 4) The possible reason for this situation is the significant difference between the intellectual sources that the two lines were fed. The Freiburg School was mostly affected by the intellectual and political climate of Germany: The concrete problems they observed in German society and the insufficiency of the dominant social science paradigms -historical school- to deal with them. On the other hand, while Hayek was originally a German speaker, there is a remarkable level of AngloSaxon influence in the formation his work as well as the inevitable influence of Austrian tradition.

\subsection{Ordo-liberal and Hayekian Conceptions of Market Economy}

For market economy Eucken uses the term Ordo which he borrowed from Thomas Aquinas. Ordo coordinates in a unique way the Creator and the world. It is a flawless order and there is only one which meets the reason and the nature of man. For Ordo-liberals competitive order (Wettbewerbsordnung) is the closest one to Ordo. But they are aware of its problems. The free, competitive Ordo is only a standard to evaluate which interventions to the competitive order can be justified. (Zweig, 1980: 20) The main problem in the Ordo-liberal conception of market economy is the private power. As we have mentioned, increasing private power not only reduces the economic freedom and welfare but also penetrates to the political life. So, institutionalized competition is not only important because it will achieve socially desired goals of growth and prosperity but also it will restrict the concentration of power in private hands. (Streit \& Wohlgemuth, 1997: 5)

For ordoliberals, competitive order can function only under a proper institutional framework. Eucken summarizes this framework with his principles of competitive market order. The constituent principles are;

- The maintenance of a properly working price mechanism free from controls (as the objective), 
- A stable currency indispensable since inflation distorts the price mechanism,

- Free entry and exit to the markets,

- Economic policies must be consistent and indicate some long run path,

- Private property,

- Freedom of contract (it must be prevented from being misused for monopolistic goals).

Besides these six constituent principles, Eucken defines regulatory principles under which the constituent principles can function: monopoly control, income policies and correction of technological external effects. Among these, ex ante and ex post regulation of monopolies is of significant importance. (Eucken, 1952; Zweig, 1980: 26) These principles of course point out the role government, which we will return in the next section.

Hayek's conceptualization of market economy starts with the problem of knowledge instead of power as we have seen in the previous section. The critical result that Hayek reached with his methodology is the importance of rules. Rules take the form of law at the societal level. So, what is necessary for a well-functioning market economy is the legal framework. Hayek (1947) emphasizes the difference between the free enterprise and competitive order. A true liberal position necessitates the support for the second. A free market economy can only created and protected under a proper legal framework. Law should protect freedoms. Freedom of contract itself for example is not sufficient to guarantee this freedom unless it is enforced under adequate legal measures. Moreover, it should be prevented from being misused by the market players in the direction of cartelization, for instance, again by legal measures. (Hayek, 1947: 115)

In (1982) and (1944) Hayek points out a dangerous tendency in western societies which may result in a degeneration of free market society and freedoms. He opposes the modern understanding of democracy, which legitimizes the rule of the majority. For him, there is an increasing misperception that if law is created by democratic procedures there is no need to further supervise it. There is a clear distinction between two statements: "Only something that is accepted by the majority bounds everybody" and "Everything that is accepted by the majority bounds everybody", the latter is in no way acceptable. (Hayek, 1982: 10) Hayek, impressed by Hume follows a critical rationalist path and rejects any understanding that may lead to any kind of "general will". (Liggio, 2000: 51) His proposal is the rule of law or legal democracy which he defines as a society where law does not affect or benefit a part of the society but is in the form of general rules that concern the whole of the society. 
Hayek also takes position against legal positivism. Legal positivism states law is man made; it is what the law maker promulgates. This law making ability is the necessity of sovereignty of the legal authority. Hayek also opposes this idea on the ground that law that can prove to be stable cannot be the product of human design but as a result of human action. It is evolutionarily inherited from earlier generations. At this point, he approaches the natural law tradition; evolutionary law takes place of the natural law of the natural law theorists. (Cliteur, 2000: 26)

\subsection{Ordo-liberal and Hayekian Conceptions of State}

Ordoliberals assigned a significant role to the competition in the market. Competition in the market has a potential to restrain economic power which results in limitation of political power. Hence, competition in the market is to be institutionalized and strongly protected by legal order. Competition policy -ordnungspolitik- was seen a genuine task for the state. This also implied that state should avoid any activities that will restrict competition. As such, Ordoliberals advocate a strong but limited state. (Streit \& Wohlgemuth, 1997: 8) State must be strong so that it will be able to resist the monopolies and pressure groups thus protecting the economic constitution, on the other hand it must be limited to pursue this aim only and respect the individual liberties. The state should also deliberately support the competition in the market through other policies.

This role of the state must guaranteed by a political constitution that has two basic properties: First, to grant independence to those who are responsible to make law and to govern, so guaranteeing political neutrality and strength against pressure groups and second, to provide necessary checks and balances for political power thus preventing arbitrary political coercion against individuals. Such a structure is the ordoliberal conception of the rule of law. -Rechtsstaat- This association of limitedness and strength should not be seen as a contradiction. Eucken makes the observation that more government activity in different areas does not mean a stronger government but on the contrary a weaker one. (Streit \& Wohlgemuth, 1997: 10)

Hayek's view on the state stems from his conceptualization of order. State itself is an organization, so it is subject to commands in its internal organization. At the same time, state is the institution that is responsible for setting up the framework of the general rules of conduct that spontaneous order of the society is based upon. This fact, Hayek thinks, leads to confusion about the role of the state in the modern societies. For Hayek, the first function of the state is its coercive function. (or protective state) Coercive function of the state is its function as the protective agent of the society which necessarily has an exclusive power to enforce "rules of the game", i.e. the legal/social rules of conduct. (Hayek, 1960: 142) 
In its second function, what Hayek calls service functions (productive state), state is involved in the market, collect taxes and provide goods and services to the society. While it is natural that it has monopoly position in its first function, it is also essential for Hayek that the first function does not (should not) extend to the second one. In its service functions government is subject to the same rules of the game as other individuals and organizations are subject to. Again, in this function, the authority the government can claim is strictly limited to which resources the individuals in the society entrusted to it. (Vanberg, 1994: 117) For Hayek, this distinction is a key to understand what is going wrong in the contemporary societies.

Types of law concerning the above-defined two functions of the state also differ. Rules of conduct on which the spontaneous order of the society is based are known as private law whereas the rules about the organization of the state coincide with the public law. Within the public law category, which is essentially related to the state, one can talk about another distinction. First, there are the rules concerned with the allocation and limitation of state's power, which are generally called constitutional rules.

The second type of rules that fall in this category is the rules that are mainly concerned with the internal organization of state and the allocation of power to different parts of this organization. Although both the rules of organization and the rules of limitation are usually found in the constitutions, it is necessary to make this distinction. The organizational rules essentially determine how a government can use the resources that are provided under its authority. (Hayek, 1973: 124-141)

On the other hand the limitation rules define the limits of this power. Hayek points out that this distinction actually refers to the two ideals of government, namely liberalism and democracy. The ideal of democracy is principally concerned with the organizational rules of the government, who and how controls the power of the government, whereas the ideal of liberalism is mainly concerned with effectively limiting the power of state. The failure to recognize this clear difference, for Hayek, is at the roots of the important problems that the contemporary societies possess. The great aim of constitutionalist movement - to limit the power of state- was given up by the wrong perception that democratic control of state power is a sufficient safeguard against its excessive growth. (Hayek, 1979)

Even though Hayek is a true liberal who is in favor of individual freedom and minimal state, his proposal is never laissez-faire. He strictly criticizes the ones who understand liberalism as the absence of state activity and instead, like ordoliberals he proposes state activity which intentionally promotes competition, market and prices as its ordering principle. For him, the state should also use the legal-institutional framework as a tool to make competition as effective and beneficial as possible. (Hayek, 1947: 108) Among the tasks he assigns to state activity are guaranteeing the freedom contract, 
regulating the markets to prevent exploitation and disciplining the trade-unions. (Hayek, 1947: 110)

\section{Conclusion: Common Grounds and Major Differences}

This section is devoted to an evaluation of the common grounds and major differences of the lines we have discussed which will also help us to make a conclusion.

\subsection{Common Grounds}

Eucken (representing Ordoliberals) and Hayek were two of the strongest proponents of the liberal line of thought both in the pre-war and post war eras in Europe. Even if Ordoliberals and Hayek started from different traditions and different backgrounds at many points they arrived at common grounds. They basically shared the same normative position about the significance of the individual liberty and thus have pursued an equally strong interest in the problems related to economic and political order. They both share the common position that "institutions matter" (Streit \& Wohlgemuth, 1997: 13) Their answer to the question "what matters about the institutions most?" was different in emphasis but not in essence. Hayek emphasizes the role of knowledge and the coordination properties of institutions related to this. Ordoliberals, on the other hand, stress the problem of power and hence the controlling properties of institutions regarding this problem. Nonetheless, none of them deny the importance of the both functions of institutions.

They also share the common normative position that individual freedom and order can be together without hampering each other. The general rules of conduct are the necessary basis for an order of the society. They both strictly reject the interventionary activism to achieve some market outcomes which they regard as arbitrary and distorting. (Streit \& Wohlgemuth, 1997: 14-16)

Besides these normative grounds, one can detect common points at their methodological backgrounds. First they both reject the common misinterpretation of the Weberian line that value judgments are totally inadmissible in social sciences, which created a fear in social scientists to express openly what they think and hampered their leading role to the politics. A second common point is the distance between both lines and the mainstream neo-classical paradigm. While this is more obvious for Hayek who comes from Austrian tradition, this statement also applies to Eucken. 


\subsection{Major Differences}

Despite having much in common on the basics the two lines have important differences at three major points: competition, institutional change and social justice.

Hayek's system, which saw competition as a dynamic "discovery procedure" rather than any kind of tool, allowed him to reject the general equilibrium framework. On the other hand ordoliberal conceptualization of competition as an "emasculating instrument" against power inevitably forced them to take general equilibrium framework as basis. In this sense Eucken's concept of "complete competition" very much resemble to the "perfect competition". This difference most obviously reflects to their views on competition policy. For Hayek, for example, it is unacceptable to take a policy measure against a monopolist in the market to force him to behave as if there was competition since the results of the competition cannot be predicted or dictated. But for Eucken, who seems to ignore the knowledge and organizational problems underlined by Hayek, the public authority should not hesitate to intervene monopolies to force them to act as if there was competition. (Streit, 1997: 16)

Hayek saw the biggest threat to the open societies in the increasing size of the state, which tries to steer the self-organizing society, whereas the biggest threat for ordoliberals was the economic interest groups faced with a weak state where inability to maintain competitive order exists. These two different positions put the two lines in different places in their attitude towards intervention. While both explicitly state their reliance on the market coordination in determining economics outcomes, Hayek trusts more on the spontaneity of the market and takes a more evolutionary position whereas Ordoliberals have suspicion that in the long run the spontaneity of the market can have desirable results for the society. They took a more constructivist position relying on the role of the economic policy in creating an order and giving considerable importance to the notion of "societal order" which is certainly against the main Hayekian thesis that the order is created by nobody. (Streit \& Wohlgemuth, 1997: 17; Goldschmidt \& Hesse: 2012: 10)

Another important point that Hayek and Ordoliberals divorce is the social justice or what ordoliberals called social question. One of the main themes of ordoliberalism was to remove the influence of Marxian line on the social question claiming social inequalities are the result of (excess) competition. Rather, the reason was the insufficient competition reflecting the failure of the state to set and preserve the competitive order. (Streit \& Wohlgemuth, 1997: 18) Hayek, on the same issue, takes a fundamentally different position. For him, the generally used term social justice is not meaningful since only human behavior can be labeled as just or unjust. The market outcomes, on the other hand, are nor just neither unjust since they are not the results of human design as Hayek repeats many times. They are the results of a spontaneous procedure from which no entity is responsible for. (Hayek, 1976: 62) 
Final words shall be on the universality of the two approaches. For us, even though it is impossible to deny that both lines have been affected by the particularity of the grounds that they were grown up, this effect is more dominant in ordoliberals. So, although both lines have significant contributions to the liberal tradition, Hayekian system seems to be a deeper and more universal line whereas ordoliberalism was fed more from the German soil and the particular experiences in Germany. This is in no way to deny that both lines can find applicability in modern societies.

\section{References}

Böhm, F. \& W. Eucken \& H. Grossman-Doerth (1989), “The Ordo Manifesto of 1936”, Peacock \& Willgerodt (eds.), in: Germany's Social Market Economy: Origins and Evolutions (London: Palgrave MacMillan), 15-26.

Cliteur, Paul (2000), "Spontaneous Order, Natural Law and Legal Positivism in the Work of Hayek", Bouckaert \& Van Der Kroon (eds.), in: Hayek Revisited (London: Edward Elgar Press).

Daumann, Frank (2007), "Evolution and the Rule of Law: Hayek's Concept of Liberal Order Revisited", Journal of Libertarian Studies, Vol: 21 No: 2, 123-150.

Eucken, Walter (1989), “What Kind of Economic and Social System?”, Peacock \& Willgerodt (eds.), in: Germany's Social Market Economy: Origins and Evolutions, (London: Palgrave MacMillan), 112-135.

Eucken, Walter (1952), “A Policy for Establishing A System of Free Enterprise”, Ludwig Erhard Stiftung (eds.), in: Standard Texts on Social Market Economy.

Fleetwood, Steve (1995), Hayek's Political Economy, (Routledge Press).

Goldschmidt, Nils \& Jan-Otmar Hesse (2012), “Eucken, Hayek and Road to Serfdom”, Freiburg Discussion Papers on Constitutional Economics, No: 12/4.

Hayek, F.A. (1964), "Kinds of Order in The Society", New Individualist Review, 3: 13-29.

Hayek, F.A. (1947), Individualism and Economic Order, (Chicago: University of Chicago Press).

Hayek, F.A. (1952), The Sensory Order, (London: Routledge \& Kean Paul).

Hayek, F.A. (1973), Law, Legislation and Liberty Vol 1: Rules and Order, (Chicago: University of Chicago Press).

Hayek, F.A. (1976), Law, Legislation and Liberty Vol 2: The Mirage of Social Justice, (Chicago: University of Chicago Press).

Hayek, F.A. (1979), Law, Legislation and Liberty Vol 3: Political Order of A Free People, (Chicago: University of Chicago Press).

Hayek F.A. (1960), The Constitution of Liberty, (London: Routledge \& Kegan Paul).

Hayek F.A. (1944), The Road to Serfdom, (Chicago: University of Chicago Press). 
Liggio, Leonard P. (2000), "Law and Legislation in Hayek's Legal Philosophy”, Bouckaert \& Van der Kroon (eds.), in: Hayek Revisited, (London: Edward Elgar), 26-52.

Schmitt, Sandra \& Adnan Ay (1998), Die Walter Eucken Bibliographie, (Berlin: Lit Verlag) Edition Walter Eucken Archiv.

Shearmur, Jeremy (1996), Hayek and After, (London: Routledge Press).

Streit, M. \& M. Wohlgemuth (1997), "The Market Economy and The State: Hayekian and Ordoliberal Conceptions”, Diskussionsbeitrag, 06-97 Walter Eucken Institut.

Vanberg, Viktor (1994), Rules and Choice in Economics, (London: Routledge Press)

Vanberg, Viktor (2001), “F.A.Hayek”, Smelser \& Baltes (eds.), in: International Encyclopedia of Social and Behavioral Sciences, (London: Elsevier), 6482-6486.

Vanberg, Viktor (2004), “The Freiburg School: Walter Eucken and Ordoliberalism”, Walter Eucken Institut Freiburg, Discussion Papers on Constitutional Economics, No: 04/11.

Zweig, Konrad (1980), "The Origins of German Social Market Economy”, Adam Smith Institute, Research Paper. 